\author{
Journal of Tourism, Hospitality and \\ Environment Management (JTHEM) \\ Journal Website: http://jthem.com/ \\ eISSN: 0128-178X
}

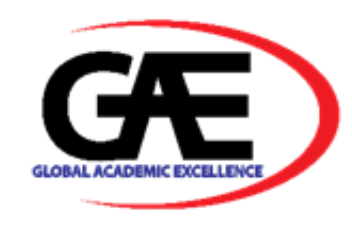

\title{
SYSTEMATIC LITERATURE REVIEWS (SLR) ANALYSIS ON NATIONAL TOURISM POLICY
}

\author{
Madzli Harun ${ }^{1}$, Noor ZatulIffah Hussin ${ }^{2}$, Khatijah Omar ${ }^{3}$, Siti Falindah Padlee ${ }^{4}$
}

1 Senior Lecturer, Faculty of Maritime Studies, Universiti Malaysia Terengganu,Kuala Nerus, Terengganu, Malaysia

Email: madzli@umt.edu.my

2 Senior Lecturer, Faculty of Business, Economic, Social Development, Universiti Malaysia Terengganu, Kuala Nerus, Terengganu, Malaysia Email: zatul.iffah@umt.edu.my

3 Associate Prof, Faculty of Business, Economic, Social Development, Universiti Malaysia Terengganu, Kuala Nerus, Terengganu, Malaysia

Email: khatijah@umt.edu.my

4 Senior Lecturer, Faculty of Business, Economic, Social Development, Universiti Malaysia Terengganu, Kuala Nerus, Terengganu, Malaysia

Email: siti.falindah@umt.edu.my

\section{Article Info:}

\section{Article history:}

Received date: 27.11.2019

Revised date: 13.12 .2019

Accepted date: 06.03.2020

Published date: 15.03.2020

\section{To cite this document:}

Harun, M., Hussin, N. Z., Omar, K., \& Padlee, S. F. (2020). Systematic Literature Review (SLR) Analysis on National Tourism Policy. Journal of Tourism, Hospitality and Environment Management, 5 (18), 122-132.

DOI: 10.35631/JTHEM.5180011.

\begin{abstract}
:
The National Tourism Policy of Malaysia is known as the National Ecotourism Plan 2016-2025. It focuses on progressive and competitive tourism in the country by giving full thrust to appreciating a prosperous environment for stakeholders in the tourism sector. Hence the study of the systematic literature review focuses on several elements as the determinants of tourism policy namely Malaysia Tourism. Consequently, each of the previous study elements will explore the scope and dimensions functionality of each scientific article is consistently discussing to analyse the year in which the authors regularly publish their publications. This is to prove that a significant element of publication by the author. Meanwhile, the scope of the study by the author also risked the priority areas in each article by the authors of each element. It is important to prove that the scope supports the main headline of the paper which deals with the formulation of the National Tourism Policy. In fact, dimensions give priority to what they want to achieve in each article from the authors related to Tourism Policy. This paper reviews the Qualitative Method concept by referring to Content Analysis. As a result, it will illustrate that dimensions will be in sync with Tourism to achieve the national tourism policy aspirations.
\end{abstract}


Keywords:

Malaysia Tourism, National Tourism Policy, Policy Formulation, Tourism

Policy, and Terengganu Tourism

\section{Introduction and Background}

Indeed, a paper is one of the highest and new literature studies to analyse the development of Literary Studies comprehensively and uniformly described amongst past research articles that should be understood by readers. An article featured has translated in detail (Dewey, A. \& Drahota, A. 2016). To process a systematic literature study has a protocol process with a structured method of rolling out detailed articles with features such as i) years of study ii) Scope of articles iii) Dimensions of the article and iv) the location of the study for the article. It is very clear to be seen by referring to the Tables laid out in this paper. In that regard, it is emphasised that the study refers in depth to the previous article published with the search of an article document. For that reason, the author has set the SLR process regularly and has certain steps that must be followed to explain and review selected articles. Accordingly, the protocol describes the meaning: -

i) How the existing research article;

ii) Analysing appropriate research articles to evaluate their use in responding to revision questions;

iii) The conclusions of the study were obtained through a comprehensive measurement and effectiveness of the selected articles associated with the statistical techniques used to combine decisions called as meta-analysis.

\section{Literature Reviews and Methodology}

According to the aspect of the methodology of this study it refers to Research Design which is quite different from the data collection aspect as it normally is; for which this study requires the method of collecting an article document through a selected Journal. While analysing the articles obtained will be analysed in Content Analysis where the determinant themes has been determined taking into account the characteristics of the theme such as year, scope of study, study dimension and study area. In this case, the author referred to the theme's facts systematically and processed in the form of data scheduling and data percentage to reflect the differences for each data to be interpreted in accordance with the chosen theme concerned.

Referring to Table 1, it describes in detail the 15 selected articles based on the keyword it is "Tourism Malaysia" which describes its features i.e. name of author, year of article, scope of study, dimension and area of study. Therefore, through the Tourism Malaysia key words, the authors have identified 15 articles that have a paper research titled. This selection refers to the title of the previous work paper which has similarities with the theme in this paper. All selected articles are very helpful in guiding the topic of this paperwork which is really supportive of the tourism industry in Malaysia which is in line with the strengthening of the National Tourism Policy. 
Table 1: Literature Review of Tourism Malaysia

\begin{tabular}{|c|c|c|c|c|c|}
\hline No & Author & Year & $\begin{array}{l}\text { Scope of } \\
\text { study }\end{array}$ & Dimension & Area \\
\hline 1. & R.J.G. Wells & 1982 & Economic & $\begin{array}{l}\text { Tourism } \\
\text { planning }\end{array}$ & General \\
\hline 2. & Joan C.Henderson & 2003 & Culture & $\begin{array}{l}\text { Tourism } \\
\text { marketing }\end{array}$ & General \\
\hline 3. & P. P. Wong & 2004 & $\begin{array}{l}\text { Environm } \\
\text { ental }\end{array}$ & $\begin{array}{l}\text { Tourism } \\
\text { planning }\end{array}$ & Penang \\
\hline 4. & Amran Hamzah & 2004 & $\begin{array}{l}\text { Strategic } \\
\text { planning }\end{array}$ & $\begin{array}{l}\text { Tourism } \\
\text { industry }\end{array}$ & General \\
\hline 5. & AbbyLiu & 2006 & Rural area & $\begin{array}{l}\text { Tourism } \\
\text { planning }\end{array}$ & Kedah \\
\hline 6. & NorlidaHanimSalleh & 2007 & $\begin{array}{l}\text { Repeat } \\
\text { tourists }\end{array}$ & $\begin{array}{l}\text { Tourism } \\
\text { demand }\end{array}$ & General \\
\hline 7. & $\begin{array}{l}\text { NorlidaHanim } \\
\text { MohdSalleh, Law Siong- } \\
\text { Hook, Sridar } \\
\text { Ramachandran, Ahmad } \\
\text { Shuib, ZalehaMohd Noor }\end{array}$ & 2008 & $\begin{array}{l}\text { Repeat } \\
\text { tourists }\end{array}$ & $\begin{array}{l}\text { Tourism } \\
\text { demand }\end{array}$ & General \\
\hline 8. & Roger Harris & 2009 & $\begin{array}{l}\text { Local } \\
\text { economy }\end{array}$ & $\begin{array}{l}\text { Community } \\
\text { development }\end{array}$ & Bario, Sarawak \\
\hline 9. & $\begin{array}{l}\text { Ghazali Musa, Kayat, K } \\
\text { and Thirumoorthi, T. }\end{array}$ & 2010 & $\begin{array}{l}\text { Environm } \\
\text { ental }\end{array}$ & $\begin{array}{l}\text { Tourism } \\
\text { development }\end{array}$ & Sipadan \\
\hline 10. & $\begin{array}{l}\text { AzizanMarzuki, } \\
\text { Iain Hay \& Jane }\end{array}$ & 2012 & $\begin{array}{l}\text { Local } \\
\text { communiti } \\
\text { es }\end{array}$ & $\begin{array}{l}\text { Tourism } \\
\text { planning }\end{array}$ & $\begin{array}{l}\text { Langkawi } \\
\text { island }\end{array}$ \\
\hline 11. & Mohd Hafiz,Hanafiah & 2013 & $\begin{array}{l}\text { Local } \\
\text { communiti } \\
\text { es }\end{array}$ & $\begin{array}{l}\text { Tourism } \\
\text { development }\end{array}$ & Tioman island \\
\hline 12. & $\begin{array}{l}\text { Chor FoonTang, Eu } \\
\text { ChyeTan }\end{array}$ & 2013 & $\begin{array}{l}\text { Tourism } \\
\text { market }\end{array}$ & $\begin{array}{l}\text { Tourism } \\
\text { development }\end{array}$ & General \\
\hline 13. & $\begin{array}{l}\text { Vikneswaran Nair, Lo } \\
\text { May Chiun and } \\
\text { SanjitSingh }\end{array}$ & 2014 & Rural area & $\begin{array}{l}\text { Tourism } \\
\text { planning }\end{array}$ & General \\
\hline 14. & Carolyon L. Cartier & 2014 & $\begin{array}{l}\text { Heritage } \\
\text { tourism }\end{array}$ & $\begin{array}{l}\text { Tourism } \\
\text { development }\end{array}$ & $\begin{array}{l}\text { Kuala lumpur, } \\
\text { Melaka } \\
\text { \&Penang }\end{array}$ \\
\hline 15. & $\begin{array}{l}\text { Ahmad Fitri,Amir, } \\
\text { AmmarAbd Ghapar, } \\
\text { SalamiahA.Jamal, } \\
\text { KhairunNajiahAhmad }\end{array}$ & 2015 & $\begin{array}{l}\text { Local } \\
\text { communiti } \\
\text { es }\end{array}$ & $\begin{array}{l}\text { Tourism } \\
\text { development }\end{array}$ & General \\
\hline
\end{tabular}

Sources: Information Search By Author From Various Journals 


\section{Discussion and Analysis of SLR}

\section{Years of SLR Study}

The discussions for SLR emphasised in detail the characteristics that has been described through the first feature analysis i) selected year of the articles. In Table 2 and Figure 1, it explains in which year the title of the previous article was published widely supporting the title of this paper. While for Figure 2, it can be interpreted as a facilitator to expose in which articles related to this paper have been published or may be cited as the development of articles related to Tourism Malaysia.

Table 2: Summary of Year Based

\begin{tabular}{|l|l|}
\hline Years of Articles & Quantities \\
\hline $2002-2003$ & 2 \\
\hline $2004-2005$ & 2 \\
\hline $2006-2007$ & 2 \\
\hline $2008-2009$ & 2 \\
\hline $2010-2011$ & 1 \\
\hline $2012-2013$ & 3 \\
\hline $2014-2015$ & 3 \\
\hline TOTAL & $\mathbf{1 5}$ \\
\hline
\end{tabular}

Figure 1: Development of Malaysia Tourism Review on literature Malaysia Tourism

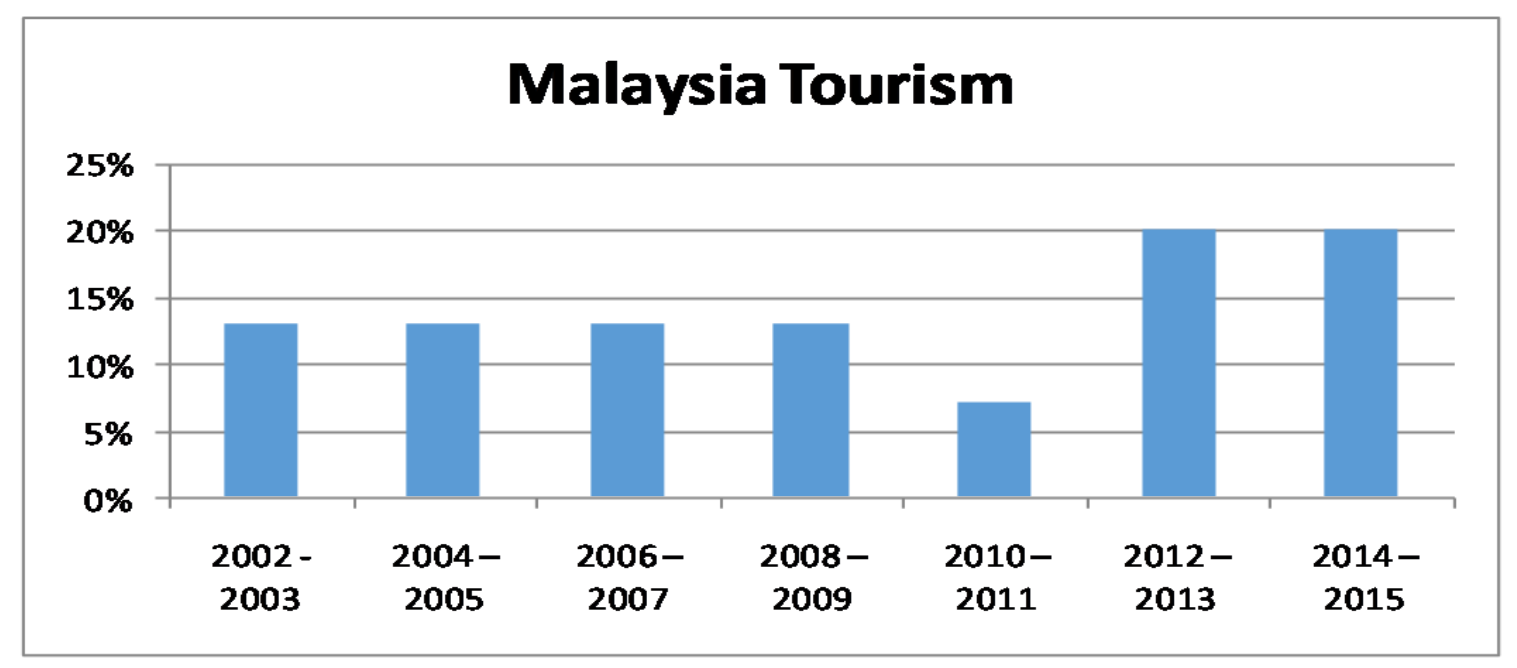

As per Table 2 and Figure 1; a total of 15 literatures were identified under keyword Malaysia Tourism for a period 2002 until 2015. For the period from 2002 until 2003, two (2) articles were found discussion on group Tourism policy for Malaysia Tourism (R.J.G. Wells, 1982; Joan C.Henderson, 2003). Both paper the planning and management of tourism in Malaysia and concerned with international tourism and the Islamic religion. While, between 2004 to 2011, more scholars had deliberated and produced literatures on sustainable aquaculture. There were seven (7) articles identified during this time frame (P. P. Wong, 2004; Amran Hamzah, 2004; AbbyLiu, 2006; Norlida Hanim Salleh, 2007; Norlida Hanim Mohd Salleh,Law SiongHook,ridar Ramachandran, Ahmad Shuib and Zaleha Mohd Noor, 2008; Roger Harris, 2009; Ghazali Musa, 2010).P. P. Wong (2004) produced an article that study about tourism 
environment that are very important and need to plan very well and Amran Hamzah (2004) produced an article of Policy And Planning of The Tourism Industry in Malaysia.

Tourism in rural areas: Kedah, Malaysia (AbbyLiu, 2006) that study about an empirical study examining the adequacy of the planning approach and establishment types in developing rural tourism in Malaysia with a focus on rural capacity to absorb tourism. An Ardl Model of Tourism Demand for Malaysiaa (Norlida Hanim Salleh, 2007) which aiming the long-run and short-run relationships among tourists' arrival to Malaysia, tourism price, substitute price, travelling cost, income and exchange rate for ASEAN-4 countries for the period 1970 to 2004 using the bounds testing co integration procedures. Besides, (Norlida Hanim Mohd Salleh,Law Siong-Hook,ridar Ramachandran, Ahmad Shuib and Zaleha Mohd Noor, 2008) produced article the long-run and short-run relationships among tourist arrivals to Malaysia and tourism price, substitute price, travelling cost, income and exchange rate for Asian7. Furthermore, six (6) literatures were found to have discussed about sustainable aquaculture from various perspectives which are 2010 to 2015. From 2010 to 2015 is the most dominant years of article were produced. Azizan Marzuki,Iain Hay \& Jane (2012) have respective article of public participation in shortcomings on tourism planning: the case of the Langkawi Islands, Malaysia. While, this paper presents the findings of a study examining the public participation approach to tourism planning in the Langkawi Islands, Malaysia. In addition, Local Community Attitude and Support towards Tourism Development in Tioman Island, Malaysia (Mohd Hafiz, Hanafiah, Mohd Raziff, Jamaluddin, Muhammad IzzatZulkifl, 2013). Redefining Rural Tourism in Malaysia: A Conceptual Perspective (Vikneswaran Nair, 2014) that discuss about redefine rural tourism in Malaysia. The objective was achieved through a content analysis of the different definitions used in selected developed and developing economies that were available in the published literature. Besides that, Conserving The Built Environment and Generating Heritage Tourism in Peninsular Malaysia (Carolyon L. Cartier, 2014) and Sustainable Tourism Development: A Study on Community Resilience for Rural Tourism in Malaysia (Ahmad Fitri Amir, Ammar Abd Ghapar, Salamiah A.Jamal and Khairun Najiah Ahmad, 2015) have been finding based on keyword Malaysia tourism that discuss about the historic built environment reflects Malaysia's population and the resiliency of the rural communities in Malaysia with the help of the sustainability planning in rural tourism.

\section{Scope of SLR Research Study}

The Scope of the SLR Research Study emphasizes the whole theme of the selected article by referring to the functionality of the articles in order to be in line with the main theme for the Tourism industry in Malaysia specializing in National Tourism Policy. Table 3 and Figure 2 represents the summary of scope of study that was focussed in the literatures related to Malaysia tourism. 15 journals of the total literatures fell under the Malaysia tourism scope, there are ten (10) scope were categorized under Malaysia tourism. Some of these literatures under the scope of local community covered mainly on the overview of tourism policy sector and review of the policies governing this industry (Amran Hamzah, 2004; Azizan Marzuki, Iain Hay \& Jane , 2012; AbbyLiu, 2006). Tourism are currently the second highest contributor to Malaysia's Gross Domestic Product (GDP) after manufacturing. Despite it is relatively late entrant as a 'big time' tourism player, the tourism industry in Malaysia has grown by leaps and bounds since the early 1990's. (Amran Hamzah, 2004).

The most dominant of scope in keyword Malaysia tourism is local community. There are three (3) article that have study about local community which is Tourism in Bario, Sarawak, Malaysia: A Case Study of Pro-poor Community-based Tourism Integrated into Community Development (Roger Harris, 2009), Public participation shortcomings in tourism planning: the 
case of the Langkawi Islands, Malaysia (Azizan Marzuki and Iain Hay \& Jane, 2012) and Local Community Attitude and Support towards Tourism Development in Tioman Island Malaysia (Mohd Hafiz, Hanafiah, Mohd Raziff, Jamaluddin Muhammad, Izzat Zulkifly, 2013). These three (3) paper are discuss about the involvement and the participation of the host community are pertinent towards the success of the tourism development plan. Public participation in decision-making processes is regarded as important for successful tourism planning.

Based on the Figure 2, there are several scope studies that have been identify as the lowest in the graph, which is heritage tourism, tourism market, local economy, strategic planning, culture and economic. The planning and management of tourism in Malaysia provides an opposite case-study of what contribution tourism can make to the economies of PDCs, and how tourism may be stimulated in such cases (R.J.G. Wells, 1982). This graph also affected by the international tourism and the Islamic religion, using the example of Malaysia as a case study to illustrate the problems and opportunities which arise when the two come into contactt (Joan C.Henderson, 2003). Besides, relationships among tourists' arrival to Malaysia, tourism price, substitute price, travelling cost, income and exchange rate for ASEAN-4 countries for the period 1970 to 2004 using the bounds testing co integration procedures (Norlida Hanim Salleh, 2007).

Table 3: Summary Scope of Research literature Study based on Study Literature Malaysia Tourism

\begin{tabular}{|c|c|c|}
\hline No. & Scope of study & Summary \\
\hline 1. & Economic & 1 \\
\hline 2. & Culture & 2 \\
\hline 3. & Environmental & 1 \\
\hline 4. & Strategic planning & 2 \\
\hline 5. & Rural area & 2 \\
\hline 6. & Repeat tourists & 1 \\
\hline 7. & Local economy & 1 \\
\hline 8. & Local communities & 1 \\
\hline 9. & Tourism market & 3 \\
\hline 10. & Heritage tourism & 1 \\
\hline
\end{tabular}




\section{Figure 2: Scope of Research Study Based On Study Malaysia Tourism}

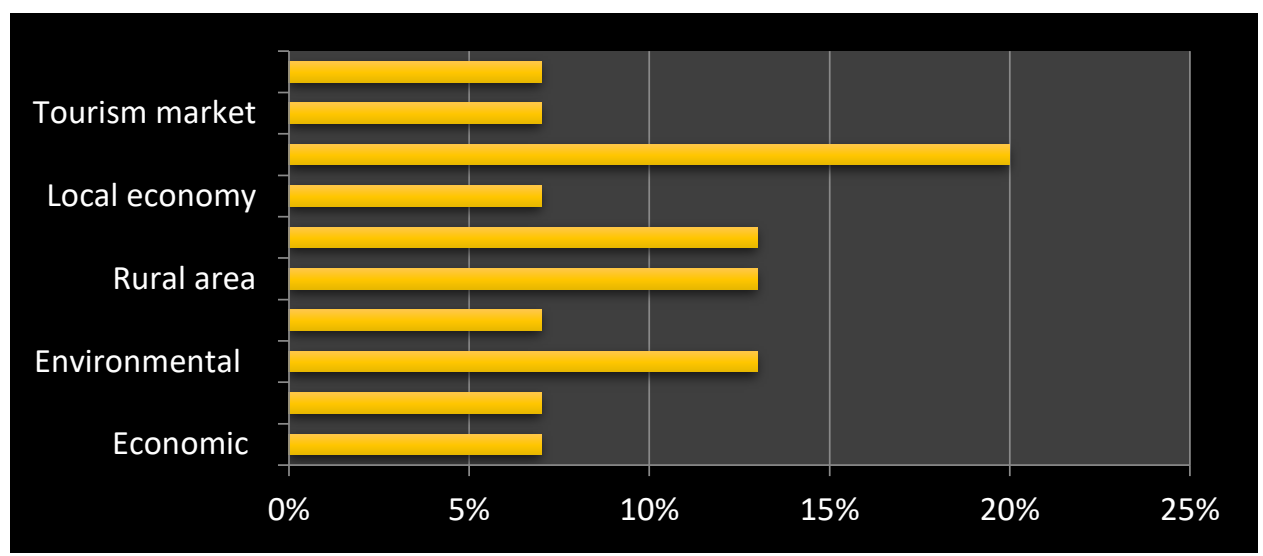

\section{Dimension of SLR Research Study}

The summary on dimension of study reflects that tourism planning was quite commonly focussed within this keyword (5 literatures), followed by tourism development ( 5 literatures) and tourism demand (3 literatures). The other dimensions were not widely emphasized. Tourism planning and tourism development seemed to be widely discussed by many scholars. For many islands, tourist development started largely as an unplanned process. In recent years, resorts have been planned and developed on some islands. The distinctive nature of the islands gives rise to specific tourism-environment relationships which can be critical for small islands (P. P. Wong, 2004). An empirical study examining the adequacy of the planning approach and establishment types in developing rural tourism in Malaysia with a focus on rural capacity to absorb tourism. It explores the policy background that encourages the growth of rural tourism and highlights issues and factors hampering the involvement of rural communities in tourism (Abby Liu, 2006). Meanwhile, objectives of Ttourism need to deal with growth leading to increased standard of living, employment levels, and opportunities for intellectual growth, enhancement of the investment potential in an area or country. Cumulatively, tourismm can be defined that objective should describe the set of conditions under which a favourable decision should be made. For the dimension of tourism demand, we can say that tourism price, travelling cost, substitute price and income are the major determinants of Malaysia's tourism demand. In the short run, repeat tourists, world economic crises and the outbreak of Severe Acute Respiratory Syndrome (SARS) significantly influence the demand for Malaysia's tourismm (Norlida Hanim Salleh, 2007). Besides, the long-run and short-run relationships among tourist arrivals to Malaysia and tourism price, substitute price, travelling cost, income and exchange rate for Asian (Norlida Hanim Mohd Salleh, Law Siong-Hook, Sridar Ramachandran, Ahmad Shuib and Zaleha Mohd Noor, 2008).

Meanwhile, tourism development was the second common dimension found this the analysis. Tourism development is an important subject in trade facilitation. In the papers produced by Ghazali Musa (2010), and Carolyon L. Cartier (2014), Tourism development is a double-edged sword for local communities and attitude directly affects the current and future tourism industry development. Community positive attitudes will encourage tourists' satisfaction levels and contributes to the word-of-mouth promotion among them (Mohd Hafiz, Hanafiah, Mohd Raziff and Jamaluddin Muhammad Izzat Zulkifly, 2013) on the other hand demonstrated how strategic environmental policy could influence the international trade. 
Table 4: Summary Dimension of Research Study Based On Literature Malaysia Tourism

\begin{tabular}{|c|l|c|}
\hline No. & Dimensions & Summary \\
\hline 1. & Tourism planning & 1 \\
\hline 2. & Tourism marketing & 1 \\
\hline 3. & Tourism industry & 2 \\
\hline 4. & Tourism demand & 1 \\
\hline 5. & Community development & 5 \\
\hline 6. & Tourism development & 1 \\
\hline
\end{tabular}

Figure 3: Dimension of Malaysia Tourism

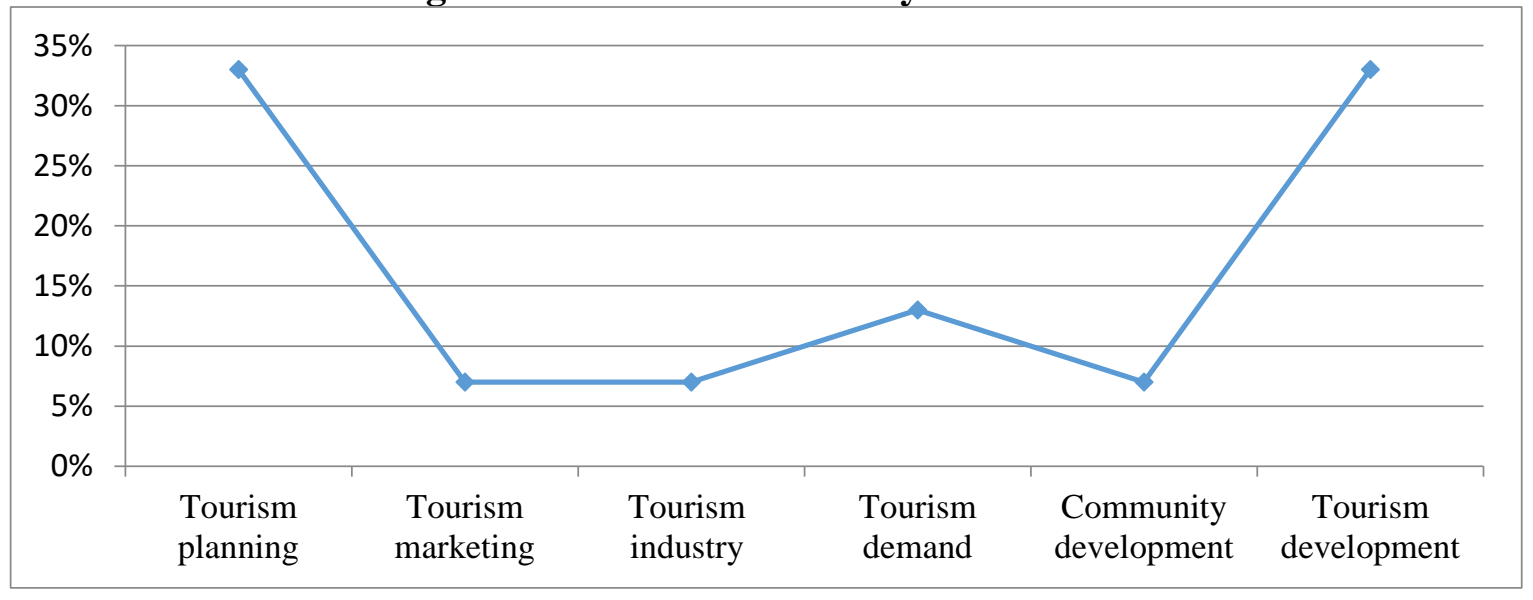

\section{Areas of SLR Research Study}

To analyse Table 5 and Figure 4 it will touch on the area that was appointed as a case study area for the previous Literature Review which has been fully addressed by the authors for previous articles. It is to examine whether the case study involved whether it involves Malaysia or not. If so, then it is felt very significant with the case study for this paper as a whole. Studies on Malaysia tourism keyword were mostly concentrated in Penang ( 2 articles), followed by other areas such as Kedah, Sarawak, Sipadan, Langkawi, Tioman island, Kuala Lumpur and Melaka with only one (1) articles each. There were also many studies which did not specify the area, as the keyword was discussed in general. The results did not tally with the total number of literatures (17) because some articles have cited more than one area. The analysis showed that studies on keyword strategic in Malaysia have not been explored widely, especially related to Malaysia tourism.

The analysis indicated that Penang was the most dominant area of research under this keyword. The literatures reflected that tourism has been applied in various scopes and dimensions including, tourism industry, strategic planning and tourism. Based on critical analysis, Tourism takes various forms on many islands off the east and west coasts of Peninsular Malaysia. Penang has developed into the premier island resort. For many islands, tourist development started largely as an unplanned process (P. P. Wong, 2005). Various approaches were implemented to support the tourism policy in Malaysia tourism, particularly to address resource 
related issues. One of the articles by Amran Hamzah (2004) stated that Tourism is currently the second highest contributor to Malaysia's Gross Domestic Product (GDP) after manufacturing. Despite its relatively late entrant as a 'big time' tourism player, the tourism industry in Malaysia has grown by leaps and bounds since the early 1990's. While tourism industry and planning was already practiced in Malaysia tourism,AbbyLiu (2006) discussed empirical study examining the adequacy of the planning approach and establishment types in developing rural tourism in Malaysia with a focus on rural capacity to absorb tourism. The remaining literatures suggested that some general observations are made about the difficulties of the relationship, and conflicts between religious practices and tourist demands are identified.

\section{Table 5: Summary Areas of Research Study on Literature Based On Literature Malaysia Tourism}

\begin{tabular}{|c|l|c|}
\hline No: & Areas & Quantities \\
\hline 1. & General & 2 \\
\hline 2. & Penang & 1 \\
\hline 3. & Kedah & 1 \\
\hline 4. & Bario, Sarawak & 1 \\
\hline 5. & Sipadan & 1 \\
\hline 6. & Langkawi & 1 \\
\hline 7. & Tioman Island & 1 \\
\hline 8. & Kuala Lumpur & 1 \\
\hline 9. & Melaka & \\
\hline
\end{tabular}

Figure 4: Areas of Research Study Based Malaysia Tourism

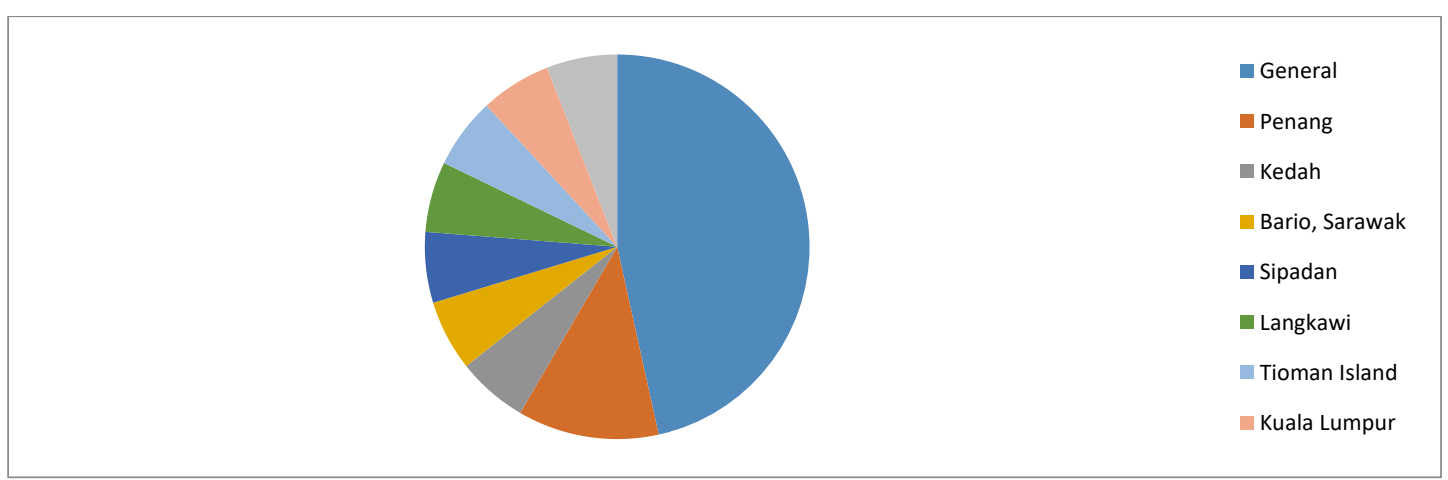

\section{Findings}

Based on Table 1; it shows that there are 15 topics that are relevant to Tourism Malaysia published by authors. It is indirectly proving that research on Tourism Malaysia is strongly emphasized in favour of the National Tourism Policy is particularly significant as the issue is strategically positioned with the lifting of unique and promising domestic tourism. Even the topics related to national tourism are often given attention by local and foreign writers supported by continued publications from 2002 to 2015 and to date however it is in different theme thrusts. Referring to Table 2 and Figure 1, articles related to Tourism Malaysia are widely published in relation to the theme of this paper is from 2012 to 2015 , which is about 3 articles publication for the two-year interval. Thus, it further stimulated the importance of the 
Tourism Malaysia theme as it should be addressed to be discussed for the strengthening of the National Tourism Policy. The second feature to consider is the Scope of Study in SLR. In this regard, referring to Table 3 and Figure, it is clear that the real analysis is that the scope of the theme of tourism among local communities, rural tourism, environmental tourism (ecotourism) has attracted visitors. It has indirectly highlighted the National Eco-Tourism Policy's weighting and is very important as the repeat tourist was added to Malaysia due to the development and development of eco-tourism which was highly emphasized by the federal government and the state government.

As a result, the theme of tourism based on writing by authors is in line with the National Eco Tourism Policy 2016. Whereas, referring to the theme of Dimension, which is really the significance of Tourism Planning and Tourism Development (see Table 4 and Figure 3). For that, it is proving that tourism in the country has been set in a unique way in which the strategic planning of tourism in Malaysia has been arranged neatly and in detail which is in line with the needs of the 2016 National Eco-Tourism Policy itself. In fact, the development of local tourism has also lifted the country's tourism industry in the best of interest and has earned its attention with the basic requirements of the best travel equipment and services and as a facilitator for tourists with the achievement of 35\% tourism development has been improved and it should be praised through past previous paper work by authors. The final findings is the theme of the tourism area, of which an average of 8 areas discussed through the Tourism Malaysia article highlighted the general tourism area in Malaysia. It means that the majority of authors discuss a comprehensive view of the tourism sector in the country without focusing on a particular area of choice. It is an effective assessment by the previous author for defining the study as a whole.

\section{Conclusion}

As a conclusion, a study on SLR based on the National Tourism Policy 2016 (Eco-Tourism) is strongly supported by every SLR theme (to four features) and is extremely mutually required and it is evidenced by the excerpts of the previous Literature Review, which coincides with the needs of tourism stakeholders and tourists visiting this country. Well! Eco-Tourism-based tourism should be appreciated and added by enforcing the National Eco-Tourism Policy.

\section{References}

Amir, A. F., Ghapar, A. A., Jamal, S. A., \& Ahmad, K. N. (2015). Sustainable tourism development: A study on community resilience for rural tourism in Malaysia. ProcediaSocial and Behavioral Sciences, 168(116-122).

Carolyn L. Cartier (2014). Conserving the Built Environment and Generating Heritage Tourism in Peninsular Malaysia, Tourism Recreation Research, Volume 21, 1996 Issue 1.

Dewey, A. \& Drahota, A. (2016) Introduction to systematic reviews: online learning module Cochrane Training http://training.cochrane.org/path/introduction-systematic-reviewspathway/1

Hamzah, A. (2004). Policy and planning of the tourism industry in Malaysia. In The 6th. ADRF General Meeting.

Hanafiah, M. H., Jamaluddin, M. R., \& Zulkifly, M. I. (2013). Local community attitude and support towards tourism development in Tioman Island, Malaysia. Procedia-Social and Behavioral Sciences, 105(1), 792-800.

Harris, R. W. (2009). Tourism in Bario, Sarawak, Malaysia: A case study of pro-poor community-based tourism integrated into community development. Asia Pacific Journal of Tourism Research, 14(2), 125-135. 
Henderson, J. C. (2003). Managing Tourism and Islam in Peninsular Malaysia. Tourism Management, 24(4), 447-456.

Liu, A. (2006). Tourism in rural areas: Kedah, Malaysia. Tourism management, 27(5), 878889.

Marzuki, A., Hay, I., \& James, J. (2012). Public participation shortcomings in tourism planning: the case of the Langkawi Islands, Malaysia. Journal of Sustainable Tourism, 20(4), 585-602.

Musa, G., Kayat, K., \& Thirumoorthi, T. (2010). The experiential aspect of rural homestay among Chinese and Malay students using diary method. Tourism and Hospitality Research, 10(1), 25-41.

Nair, V., Chiun, L. M., \& Singh, S. (2014). The international tourists' perspective on Malaysia's Economic Transformation Programme (ETP). Procedia-Social and Behavioral Sciences, 144, 433-445.

PP Wong (2004). Chapter 36 Environmental Impact on Tourism: A Companion Tourism., edited by Alan A. Lew, C. Michael Hall, Allan M. Williams, Black Well Publishing Ltd, Oxford, UK.

Salleh, N. H. M., Othman, R., \& Ramachandran, S. (2007). Malaysia's tourism demand from selected countries: The ARDL approach to cointegration. International journal of economics and management, 1(3), 345-363.

Salleh, N. H. M., Siong-Hook, L., Ramachandran, S., Shuib, A., \& Noor, Z. M. (2008). Asian tourism demand for Malaysia: A bound test approach. Contemporary Management Research, 4(4).

Tang, C. F., \& Tan, E. C. (2013). How stable is the tourism-led growth hypothesis in Malaysia? Evidence from disaggregated tourism markets. Tourism Man 